\title{
BEHAVIOR AND MARKETING MIX FACTORS INFLUENCE TO USE SHELL PETROL STATION SERVICES IN UDON THANI PROVINCE THAILAND
}

\author{
Narongsak Poopiw ${ }^{1}$ \\ Master's Degree, Marketing, Business Administration and Accountancy, Khon Kaen University, Thailand. \\ (Email: Poopiwnn@gmail.com) \\ Associate Professor Dr. Nitipol Phutachote ${ }^{2}$ \\ Marketing Lecturer, Business Administration and Accountancy, Khon Kaen University, Thailand. \\ (Email: nitput@kku.ac.th) \\ Associate Professor Dr. Pensri Jaroenwanit ${ }^{3}$ \\ Marketing Lecturer, Business Administration and Accountancy, Khon Kaen University, Thailand. \\ (Email: penjar@kku.ac.th)
}

Received date: 22-02-2019

Revised date: $14-04-2019$

Accepted date: 19-07-2019

Published date: 15-09-2019

To cite this document: Narongsak, P., Nitipol, P., \& Pensri J. (2019). Behavior and Marketing Mix Factors Influence to Use Shell Petrol Station Services in Udon Thani Province Thailand. International Journal of Entrepreneurship and Management Practices, 2 (7), 19-25.

DOI: $10.35631 /$ ijemp. 27003

\begin{abstract}
The purposes of this study were behavior and marketing mix factors influence to use shell petrol station services in Udon Thani province Thailand. A sample was selected from 400 people was used for data analysis data was analyzed using descriptive statistics such as the frequency, percentage, mean, and standard deviation and also inference statistics in an independent sample T-Test for comparing the different of two groups of samples and then One-way Anova or F-test for testing the difference more than two groups. The findings indicated that the majority of respondents were male, aged between 21-30 years, which the average income was 10,001-20,000 Thai Baht per month. The reasons of choosing was traveled, convenience and quality. They were using between 6-10 am and $5 \mathrm{pm}$. Overall, respondents were satisfied with the marketing mix service at a high level. When considering the list as they found that the respondents were satisfied with most of the products, price, place, promotion, process, personnel, performance and quality of service including physical.
\end{abstract}

Keywords: Behavior, Marketing Mix, Shell Petrol Station Services

\section{Introduction}

Oil or petroleum that got from fossils and plants was wastefully flue which pumped out the underground and passed the processed by used high-temperature and became the products such as gasoline. Diesel, jet fuel, gas, liquefied petroleum gas, kerosene, fuel oil, )Petroleum 
Authority of Thailand, 2560), the products would able more benefits direct and indirect and the quality will have been developing every time for improving technology in the automobile industrials that they achievements and always develops oil quality to highest volume . On behalf of the leader global fuel technology Shell Thailand had to research and development oil continually by co-operated with global partnerships. On the other hand, PTT, PT, Bangchak, Esso and Caltex, they had a role in the petroleum and chemical industries in Thailand.

Oil was a really important resource because related to our daily life, such as traveled, transportations, productions, consumer goods, industrial, and services because the customers expect best services, so petrol station are important to provide what consumers needed. Shell Thailand the one of expert about oil and petrol station services in Thailand. In the situation that the oil market has many competitors which affected to petrol station, so the entrepreneurs should focus on the expedite of creating strategies, especially high quality products including with the place enough to the consumers, create promotions, personnel and the quality of service. In order to be adapting quickly and gained the advantages over other competitors. One of the most important factors that helped accomplishment in business was selecting the appropriated model of proceeds meant to extend business strategy and another thing was creating point of sale such as area creating promotion.

As everyone know, the petrol station services have more competitors, but we also keep the customers and adding new customers' data because it's been important to the business, so the researchers studied the behavior and marketing mix factors that influence they used of the Shell petrol station services. Shell Company of Thailand Co., Ltd. in Udon Thani) would be a guideline to developing quality and service to consumers. The most importantly, we could bring our strategies to handle with oil market and respond to the consumers needed.

\section{Objectives}

1. Studies the personal factors used Shell petrol station services in Udon Thani

2. Studies the consumer behavior that they used Shell petrol station services in Udon Thani

3. Studies the marketing mix factors influence to use Shell petrol station services in Udon Thani

\section{Scope of the Research}

A quantitative research tool was used to collect data from the Shell Oil Station in Udon Thani by surveying the sample. The questionnaire was used to examine the users of the Shell Oil Station at that time.

\section{Literature Review}

Literature review the consumer's behavior survey means investigate the consumer ) Searching(, Purchasing, Using, Evaluating and Expense in the term of products and what service that made the consumer get satisfied. (Schiffman \& wisenblit, 2015)

Macdonald \& Wilson (2016) Marketing mixed using the marketing tools in accordance with information processing for motivating consumers would attend.

Kapoor, Raul and Halder (2011) services is process that consumer used services. We always offer the best service to all consumers around the world by our professional provider and also 
offered benefits services not only keeping but we also improve the quality for made them felt convenience and really impress.

Schiffman \& wisenblit (2015) the process would be have been element for consumer decided by himself and they consider physical such as learning, perception, personality and attitudes will affect to decision making for selecting and evaluation before decision.

\section{Research Methodology}

The sample were people who came in to use the Shell petrol station services at that time the total is 384 people. For easier to evaluating and analyzing data the researcher applied sample totally 400 people which followed the regulation and conditions not less than 384 refers to Taro Yamane formula with reliability level $95 \%$ and determined incorrect but could accepted .05 .

The tools for researching were closed-ended questionnaire divided by 3 sections;

Section 1: Checklist items answered about personal information of each other included with age, salary, education and career.

Sections 2: The questions asked about the behavior of each person in a specific area they were using shell petrol satiation service in Udon Thani.

Sections 3: The data related with strategies and had influenced to choose services to consumers.

\section{Research Tool}

The researchers had been created the method how to cover the data for the following below.

1. Learning and finding the documents, research, text, content, website and supporting reference.

2. Created full specification information data sheet and consulted with professor for recheck and got some advised for amendment to suit with our objectives.

3. Submitted to professor for correcting greatly again before started to do.

4. Started to examine for finding the average of reliability of data by tryout with 30 samples and followed the method of Cronbach's Alpha Coefficient. We got the reliability result total .835

5. Bring all passed the questionnaire to reviewed and then applied to sample with 400 sampling.

\section{Statistics Used to Analyze Data}

After we collected all of completed information the researcher would put coding on SPSS programs and calculating the statistics of analysis for the following data.

Descriptive statistics we were applying for separating the frequency, percentage, means and standard deviation are used to describe the questionnaire and behaviors.

Inferential statistics use in test hypotheses in research to concluding citations for study populations and information in the questionnaire related with satisfaction level.

Normally the statistical test will be relation between factors and define statistically significant correlations or not. Independent Sample T-Test for comparing the diverge between two group average and also One-way analysis of variance (One - Way Anova) or F-test to test the difference between the mean of the sample groups with more than 2 groups. If there were significant differences at .05 significance level. LSD (Least Significant Difference) 


\section{Research Result}

Test Results Hypothesis

Assumption 1 Age factors different that affected to marketing mix and also selection of different Shell stations summarized below.

- Users different ages that they had influenced to the marketing mix and choose Shell stations was really differ from promotions were statistically significant at .05 levels.

Assumption 2 Salary factors have different that influenced to the marketing mix for selection Shell stations summarized below.

- User that they were different salary and had influenced to the marketing mix for selection Shell stations, in the part of sales promotions, personnel, and physical were statistically significant at .05 levels.

Assumption 3 Educational factors had different and also affected to the marketing mix for selection Shell stations summarized below.

- Users that they had different educations levels and affected to the marketing mix for selection Shell was different in the part of products, place, sales promotion and physical were statistically significant at .05 levels.

Assumption 4 Occupation factors had different and also affected to the marketing mix for selection Shell stations resulted below.

- Users that they were many different occupations and affected to the marketing mix for selection Shell stations was different in the part of products, sales promotion were statistically significant at .05 levels.

\section{Discussion of Results}

As observation in behavioral section that inductive to Shell petrol station services in Udon Thani. The users really satisfied with convenience. Later, it was found that the customers frequently refuel at the gas station. Likewise, those who influence the decision to option for the gas station it's was themselves. The customers also have the optional to pay for gas station services the cost between 501 - 1,000 Baht, users would be use the services station at 17.01 hours or more and the user had to use the services station from 1-5 times per month. Based on this data, Kotler (2012) had commented that it's was a study of consumers behavior, individuals and organizations. Use the products or service, or choose from the experience.

From our studied the marketing mix factors, the service had influenced with Shell petrol station services in Udon Thani. We found that genders not different to the marketing mix but ages were differential in the parts of sales promotion and the salary also different in the part of sales promotion, personnel, and physical. We also had the status were different amount sales promotion and efficient. Refer to previously according to Macdonald \& Wilson (2016), marketing mix we could use the strategies in the right objectives and also agreeable to data proceed for motivation or encouragement the consumers to interested and more over A.StoneMarilyn\& John Desmond (2007) said that the marketing mix it helped us decision that involved with the way of marketing mix element for setting up the cost of products, promotions, place and distribution channel such as when we needed to ensure about our champagnes to supporting promotion and also would apply technique for checking our efficient after we examined the market. 
Based on the hypothesis testing, the researcher found about used petrol stations service. Chirattha Moayadee )2013) told us about the most affected to the consumer would select used petrol stations and the issue of PTT, in Lampung province she found that the consumers often selected convenience fist means 3-4 time of each month and overall the consumers were impress with service level on the other hand we able created strengths points and also adopted weakness points reference to Eric Riedel (2017) Marketing Strategies to enhance profitability among international oil gas services said that the best services able to adding more benefits to organization according to Panupong Wongsa )2011) said that the marketing strategy and strategies management able to increase the retail market business performance of fuel service stations in case of Bangchak Petroleum Public Company Limited. Growth strategies by using the products she found, strategies business-level and duties of strategies was creating defensive point for added value of the products.

\section{Suggestion}

\section{Suggested Research}

From our studied behavior had influenced to use Shell petrol station services in Udon Thani. Found that conscience, comfortable, overpass, owner, cash, 501-1,000 bath, at 17.01, 1-5 or each month which of each role were impressed, the researcher had comment that we should have crating promotion in section of voucher like when consumer came to fuel the gas we would give café voucher to them and also free car wash. The period consumers not quite mush such as 10.01- 12.00 and 12.00-15.00 we might launch champagne or announced new released information example free car maintenance, food vouchers for motivate consumers wanted to use our service.

Marketing strategies factors into selection Shell petrol station services in UdonThaniThani. Products was highest level of satisfaction as the products had reliability, well-timed, products reputation, variety products the researcher commented that should keep standard also more developing.

Price was a high level of satisfaction in the second order. The service fee is clear, charge by credit card, faire price, the researcher commented that price also higher than the competitor which may be used by the customer to use the competitor's petrol station, so he or she may be able to give discounted fuel surcharge to buy a coffee or discount check car maintain for increasing the satisfaction of the consumers.

Physical was a high level of satisfaction in the third order because they had big label, fantastic interior and appropriate uniforms, unique, clean spacious and modern but the researcher commented told us that In the field of decoration, spacious and clean was minimum satisfaction because Shell petrol station services in Udon Thani should be keep clean of car wash and car maintenance room.

Process was a high level of satisfaction in the fourth order which had queue, appropriate service order, quickly to provide consumers but the researcher commented Shell petrol station services in Udon Thani would have training staff for make sure they ready to serve our consumers.

Place was a high level of satisfaction in the fourth order which had may channel to pay, cleaning areas, enough car parking, located easy to find and comfortable. The researcher commented might lift up more clean for consumes happy to see all clean. 
Personnel was a high level of satisfaction in the sixth order as staff knowing about products, always took care consumers, staff always smiled but staff not enough because consumers they couldn't wait to long time.

The efficient and quality of services was a high level of satisfaction in the seventh order which Shell petrol station services in Udon Thani used high standard equipment, handle issue very well, but sometimes might set training about how to use equipment for recheck staff didn't forgot the way to use is.

Promotions was a high level of satisfaction in the eight order which the part of advertisements.

Announcements via variety channel, activities that make relationship with consumers, give discount, but which Shell petrol station services in Udon Thani would expand public relations for getting connection to new comer consumers to know about activities or promotions.

\section{Suggestions for The Next Study}

Suggestions for the next study1.In this study, there was scope for studying of customers who came to Shell petrol station services in Udon Thani. The data is not wide enough. Therefore, in the next study, those who had similar subjects should study more samples. The questionnaire was collected in other provinces for further analysis

The behavior and marketing mix factors influence to used Shell petrol station services in UdonThani should be studies and comparing with other petrol station for collecting and correct the data of marketing plan, marketing strategies and developed in overall to get the efficiency and also improved as well as the most effective to users and visitors.

\section{References}

A. Stone Marilyn \& John Desmond. (2007). Fundamentals of Marketing. New York: Routledge.

Chatchayaporn Sameijal 2007( Behavior refers to the process of making decisions about buying, using, evaluating the use of products or services of individuals. Which will be important for the purchase of both current and future products.

Chirattha Moayadee. )2013(. CONSUMER BEHAVIOR IN CHOOSING PTT GAS STATIONS IN AMPHOE MUANG OF LAMPANG PROVINC. Independent Study Master of Business Administration National University.

Eric Riedel. (2017). Marketing Strategies to Enhance Profitability Among International Oil and Gas Service Companies. Ph.D. Thesis, College of Management and Technology, Walden University.

Kawpong Polyorat )2016( comment that the population will have a sub-value to be interpreted to answer the question of that research.

Kotler )1997( Service is the expectation of value and proceeds according to standards. When consumers buy products, consumers need services that bring value and satisfaction.

Leon G. Schiffman \& Joseph L. Wiscnblit. (2015). Consumer Behavior )11thed.(. New Jersey: Pearson.

Malcolm Mcdonald \& Hugh Wilson. (2016). Marketing Plan )8thed.(. England: Wiley.

Nitipol Phutachote )2017( The service cannot be tangible and visible. There is no form, no identity, but those things can be perceived by the feelings or expressions of the client, such as likes, hate, satisfaction and discontent. 
Nonglak Jaruwan)2017( The customers will select brand for recognize that they like or don't like. Attitude will help to decide what they buy and come back to buy again. However, experience have impact to decision.

Ramneek Kapoor \& Jostin Raul \& Biplab Halder. (2011). Service Marketing. New Delhi: Mc Graw Hill Company.

Siriwan Serirat )2007( The process of consumer decision-making process has five steps, one is to recognize the need or perceive the problem. Two data searches, Three, evaluation options before buying, Four, buying decisions Five, consumer behavior after buying.

Sudadung Rengrujira )1998( Service is an intangible job but able to create satisfaction in responding to the needs of consumers in the business market. Therefore, the service should have quality so it will benefit the organization and succeed.

Sukon Prasitwattanaseree )2006( Population is a variable that represents specific characteristics such as gender, age, income, occupation, and status is the data used to calculate the population or the frequency of the incident at a certain time.

Sutthichai Panyaroung )2014( Standard maintaining service is very difficult. General products cannot measure the quality, quantity, and appearance clearly but the service in particular, service with that person must maintain the standard in the service, therefore must be trained properly.

Tanin Sinjaru )2014( Said that population is segmentation in order to demography such as sex, income, age, career, education and status is popular to separate part of marketing will show the important and set the goal of education.

Yapawan Vanvanich )2006( The service market is creating value for consumers in order to make consumers satisfied. The service business cannot be maintained and tangible but can impress consumers and visitors. 